Original Research / Özgün Araştırma

\title{
Antenatal Care and Breastfeeding
}

\author{
Doğum Öncesi Bakım ve Emzirme Davranışı
}

İknur Göl $l^{* 1}$

\begin{abstract}
Aim/background: There is a positive effect on the mother's breastfeeding behaviors in giving breastfeed and breastfeeding counselling as a standard part of antenatal care. This study was performed with the aim to investigate the effect antenatal care on the breastfeeding behavior of mothers with the 0-24 month old baby. Methods: The sample of this descriptive, crosssectional study included 141 mothers presenting to two family health care centers between March and June in 2016 and having a 0-24- month-old baby. Data were collected at face-to-face interviews with a questionnaire created by the researcher and was composed of a total of 33 questions, of which nine were about socio-demographic features, 13 were about the history of pregnancy and antenatal care and 11 were about breastfeeding. Data were analyzed with percentages and Chi-square test. Results: Mothers receiving breastfeeding counselling during antenatal care started to breastfeed their babies earlier and breastfed them for longer periods of time. Conclusion: Counselling in breast milk and breastfeeding during pregnancy has a significant effect on the earlier initiation of breastfeeding and exclusive breastfeeding for the first six months of life. B ased on the results of the study, it can be recommended that breastfeeding counselling should be offered continuously.
\end{abstract}

Keywords: Breastfeed, antenatal care, breastfeeding behavior

\section{ÖZET}

Amaç/giriş: Anne sütü ve emzirme konularındaki eğitimlerin doğum öncesi bakımın standart bir parçası olarak verilmesinin, annelerin emzirme davranışları üzerinde olumlu etkisi vardır. Bu çalışmanın amacı, aile sağlı̆̆ı merkezlerine başvuran 0-24 aylık bebeği olan annelerin doğum öncesi bakım alma durumlarının emzirme davranışlarına etkisini değerlendirmektedir. Yöntem: Kesitsel tanımlayıcı tipteki bu çalışmanın örneklemini iki Aile Sağlığı Merkezine Mart-Haziran 2016 tarihleri arasında başvuran 0-24 aylık bebeği olan 141 anne oluşturmuştur. Verilerin toplanmasında araştırmacı tarafindan literatür doğrultusunda hazırlanan ve annelerin sosyo-demogrofik özelliklerini belirlemeye yönelik 9, gebelik ve doğum öncesi bakım öykülerine yönelik 13 ve emzirmeye yönelik 11 soru olmak üzere toplam 33 soru içeren bir anket formu kullanılmıştır. Veriler araştırmacı tarafından yüz yüze görüşme tekniği ile toplanmıştır. Verilerin değerlendirilmesinde yüzdelik dağılım ve ki-kare testi kullanılmıştır. Bulgular: Anne sütü/emzirme eğitimi alanların almayanlara göre bebeklerini daha erken dönemde emzirmeye başladığı ve daha uzun süre emzirdiği belirlenmiştir. Sonuç: Gebelik döneminde anne sütü ve emzirme konularında eğitim almanın erken emzirmeye başlama ve ilk altı ay sadece anne sütü ile beslenme üzerinde anlamlı etkisi vardır. Doğum öncesi bakımın bir parçası olarak anne sütü/emzirme eğitimi verilmesi önemlidir.

Anahtar kelimeler: Anne sütü, doğum öncesi bakım, emzirme davranışı

Received Date / Geliş Tarihi: 05.12.2017, Accepted Date / Kabul Tarihi: 20.03.2018

${ }^{1}$ Çankırı Karatekin Üniversitesi Sağlık Bilimleri Fakültesi Hemşirelik Bölümü Halk Sağlığı Hemşireliği AD. Çankırı TÜRKIYE

*Address for Correspondence / Yazışma Adresi: İlknur GÖL, Çankırı Karatekin Üniversitesi Sağlık Bilimleri Fakültesi Hemşirelik Bölümü Halk Sağlı̆̆ı Hemşireliği AD. Çankırı TÜRKIYE E-mail: ilknurnayirgol@gmail.com

Göl İ. Doğum Öncesi Bakım ve Emzirme Davranışı. TJFMPC, 2018; 12 (2): 102-108. DOI: 10.21763/tjfmpc.432466

Göl İ. TJFMPC www.tjfmpc.gen.tr 2018; 12(2) 


\section{INTRODUCTION}

The World Health Organization (WHO) defines antenatal care as the follow-up of mothers and their fetuses once or more than once during pregnancy by health professionals. ${ }^{1}$ The goal of this follow-up is to help women to experience a healthy pregnancy and to give birth to a healthy baby. ${ }^{2}$ Antenatal care is composed of three main components, i.e. evaluation and protection of mothers and their fetuses' health, counselling and education related to health and treatment services. ${ }^{2,3}$ Since early diagnosis in pregnancy is important, the WHO and Canadian Gynecology and Obstetrics Association has recommended initiation of antenatal care as early as possible. ${ }^{1,4}$ It is stated in Antenatal Care Management Guide, prepared by Turkish Ministry of Health, that follow-up of pregnant women should be initiated in the fourteenth week of pregnancy and should be performed at least four times during pregnancy. ${ }^{5}$ The WHO reported that $68 \%$ of the women in developing countries and $98 \%$ of women in developed countries receive antenatal care. ${ }^{6}$ According to data from Turkish Population and Health Study (TPHS) in 2013 the rate of women receiving antenatal care in their last pregnancy in Turkey is 97\%.7 Another important issue concerning mothers' and their babies' health is breastmilk and breastfeeding. It is well known that breastfeeding plays an essential role in survival, growth and development of babies. ${ }^{8}$ As well as the promotion of mothers' and their babies' health, breastfeeding enhances mother-baby bonding and is cost-effective. ${ }^{9}$ It has been noted in the literature that breastfed babies have lower risk of insulindependent diabetes, sudden infant death syndrome, childhood cancers and obesity than those not breastfed. ${ }^{10-12}$ Therefore, the WHO and American Pediatric Academy recommend that breastfeeding should be started within the first hour of birth and that babies should only be fed with breastmilk in the first six months of birth and continue to take breastmilk for two years. ${ }^{13,14}$ The most recent scientific evidence indicates that exclusive breastfeeding (only breastmilk, no food or water except vitamins and medications) for the first 6 months is associated with the greatest protection against major health problems for both mothers and infants. ${ }^{15}$ An institution of breastfeeding in the first hour of birth is important in terms of release of breastmilk and maintenance of breastmilk production as well as early cessation of postpartum bleeding and prevention of complications likely to appear in breasts, which facilitate lactation. Since the first breastmilk released (colostrum) contains high concentrations of antibodies, it protects newborns against infections. ${ }^{16,17}$ Despite all these positive aspects of breastfeeding, rates of breastfeeding are not as high as expected. In addition to low rates of breastfeeding, many women end breastfeeding earlier than recommended by authorities. It is estimated that feeding babies in accordance with recommended breastfeeding practices can help save lives of 1,5 million babies. ${ }^{8}$ Based on data from TPHS 2013, 50\% of babies are breastfed in the first hour of birth, $26 \%$ of babies are fed with food other than breastmilk and $58 \%$ of babies are only given breastmilk in the first two months of their lives in Turkey. ${ }^{7}$ The rate of exclusive breastfeeding drops as the age of babies increases and decreases to $10 \%$ in babies aged $4-5$ months. It has been reported that incorporation of counselling about the importance of breastmilk and breastfeeding, benefits of breastfeeding for both mothers and babies, initiation of breastfeeding and breastfeeding techniques into antenatal care can be effective in early start of breastfeeding, exclusive breastfeeding in the first six months of life and improvement of breastfeeding rates. Evidencebased guides also recommend that training involving practices of breastfeeding should be offered to support breastfeeding. ${ }^{18,19}$ In light of evidence from the literature and abovementioned guides, this study was conducted to the effect of antenatal care on the breastfeeding behavior of mothers with the 0-24 month-old baby

\section{METHODS}

\section{Study design}

This study has a descriptive, cross-sectional design.

\section{Study setting}

The study was performed in two family health care centers in the center of a city in Middle Anatolia in Turkey. Six family health care centers are located in the province when the study is carried out. The study was performed in two family health care centers with the highest population density.

\section{Study population}

The study population included all women presenting to two family health care centers for any reason between March and June in 2016 and having a baby aged 0-24 months. On March-June 2016, 160 women presenting to family health care centers. Women were informed about the purpose of the study and the content of the questionnaire. The study was conducted with 141 women, as twenty-one women did not want to participate in the study. The study was conducted with $87 \%$ participation rate.

\section{Inclusion criteria}

Women who were older than 18 years, spoke Turkish, having a baby aged 0-24 months and 
volunteered to participate in the study were included in the study.

\section{Exclusion criteria}

Women who had a chronic disease that would prevent breastfeeding were excluded from the study.

\section{Data collection tools}

Data were collected with face-to-face interviews using a questionnaire created by the researcher and included a total of 33 questions, of which nine were about socio-demographic features, 13 were about history of pregnancy and antenatal care and 11 were about breastfeeding. ${ }^{16-20}$

\section{Data analysis}

Obtained data were analyzed with descriptive statistics, and Chi-square test for detection of a relation between dependent and independent variables. $\mathrm{P}<0.05$ was considered significant for evaluation of results of statistical analyses.

\section{Ethical considerations}

Ethical approval was obtained from the ethical committee of a university in Middle Anatolia and permissions were obtained from the public health directorate of the city where the study was conducted. The mothers in the study population were informed about the study and oral informed consent was taken from those voluntarily accepting to participate in the study.

\section{RESULTS}

Forty-one point eight percent of the mothers were aged 20-24 years and the rate of the mothers aged 35 years or older was $7.1 \%$. Thirty-eight points three percent of the mothers were primary school graduates, $35.5 \%$ of the mothers were high school graduates, $81.6 \%$ of the mothers were a housewife, $51.1 \%$ of the mothers were married to a high school graduate and $69.5 \%$ of the mothers were married to a worker. Fifty-one point six percent of the mothers got married at the age of 20 years or at a younger age and $52.5 \%$ were aged 21-25 years when they first got pregnant. Forty-two point six percent of the mothers had one pregnancy, $15.6 \%$ of the mothers had one spontaneous abortion and $14.2 \%$ of the mothers had one induced abortion. Seventy-five point two percent of the mothers underwent caesarian section and $24.8 \%$ of the mothers gave vaginal birth (Table 1).

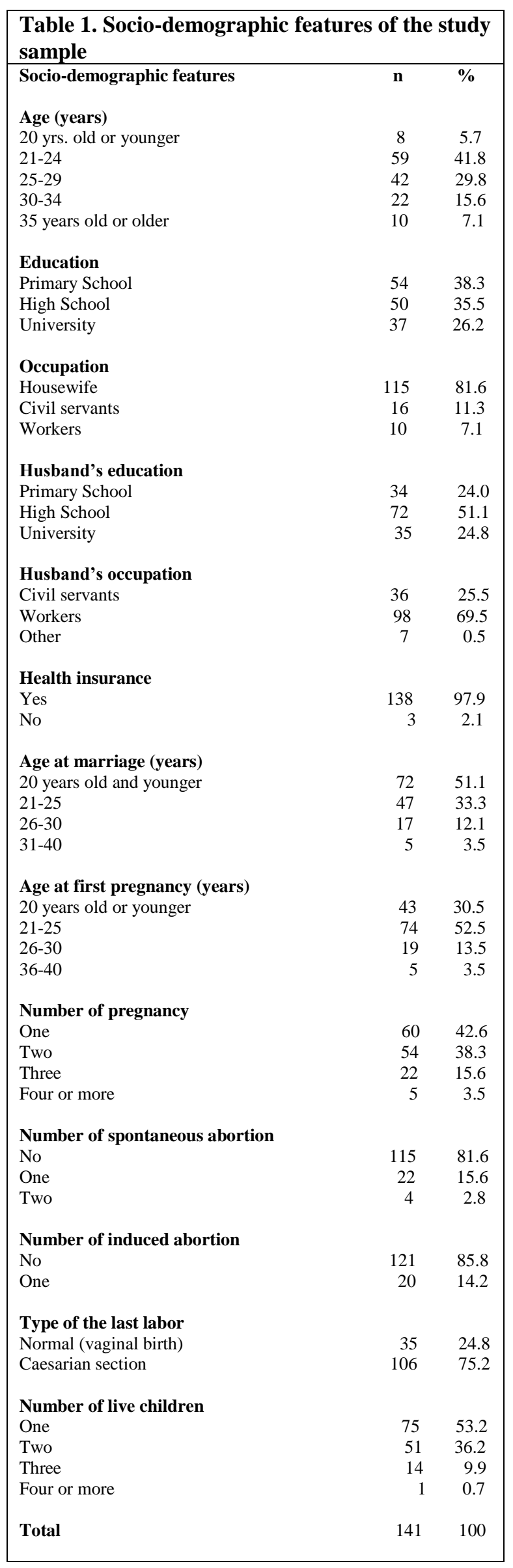


Ninety-two point two percent of the mothers reported to receiving antenatal care in their last birth while $7.8 \%$ of the mothers reported they did not need it. Eighty-nine percent of the mothers receiving antenatal care noted that they started to get care in the fourth-eighth week of their pregnancy. Thirty-three point three percent of the mothers got antenatal care 5-6 times during their pregnancy and $47.5 \%$ of the mothers got this care from family health care centers. Seventy-one point six percent of the mothers receiving antenatal care were offered to counselling about breastfeeding (Table 2). There was no significant relation between receiving antenatal care and descriptive characteristics including age, education, number of pregnancies, spontaneous abortion and induced abortion ( $\mathrm{p}>0.05)$.

\begin{tabular}{|lcr|}
\hline Table 2. Receiving antenatal care & & \\
\hline & $\mathbf{n}^{*}$ & $\%$ \\
Antenatal care & & \\
& & \\
None & 11 & 7.8 \\
$1-2$ & 10 & 7.1 \\
$3-4$ & 27 & 19.1 \\
$5-6$ & 44 & 31.2 \\
$7-8$ & 13 & 9.2 \\
9 or more & 36 & 25.5 \\
& & \\
Time of the first follow-up visit & & \\
& & \\
$4^{\text {th }}$ - $^{\text {th }}$ weeks & 119 & 89.3 \\
$9^{\text {th-16 }}$ weeks & 14 & 10.8 \\
& & \\
Place of antenatal care & & \\
& & \\
State hospital & 33 & 24.8 \\
Family health care center & 67 & 50.4 \\
Private hospital & 33 & 24.8 \\
& & \\
Subjects about which information & & \\
was given during antenatal care & & \\
& & \\
Nutrition & 102 & 72.3 \\
Risks in pregnancy & 69 & 48.9 \\
Labor & 70 & 49.6 \\
Postpartum care & 92 & 65.2 \\
Breastmilk/breastfeeding & 101 & 71.6 \\
Family planning & 79 & 56.0 \\
& & \\
\hline
\end{tabular}

* The total was not expressed since one participant selected more than one statement.

Twenty-seven point seven percent of the mothers breastfed their babies. Eighty percent of the mothers giving vaginal birth and $10.1 \%$ of the mothers undergoing caesarian section breastfed their babies after giving birth with a significant difference $(p<0.05)$. In addition, the rate of the mothers breastfeeding in the first hour of birth was $28.4 \%$. Seventy-seven point one percent of the mothers giving vaginal birth and $1.9 \%$ of the mothers having caesarian section breastfed their babies within the first hour of their giving birth with a significant difference $(p<0.05)$. About half of the women having the caesarian section $(42.5 \%)$ reported to breastfeed their babies within the tenth hour after birth or later. Nine point two percent of the mothers having a baby aged 6-24 months and $9.8 \%$ of the mothers having a baby aged 6-24 months fed their babies only with breastmilk for the first six months. Of all the mothers receiving to counselling about breastfeeding during antenatal care, $35 \%$ started breastfeeding for the first one hour of giving birth and $22.5 \%$ gave their babies only breastmilk for the first six months of their babies' birth. Of all the mothers not offered counselling about breastfeeding, $12.5 \%$ breastfed their baby within the first hour of birth and $2.5 \%$ gave their babies only breastmilk for the first six months of life. The difference between the mothers getting counselling about breastfeeding and those not getting any counselling about it was significant $(p<0.05)$ (Table 3). However, there was no significant relation between breastfeeding for the first six months of life and descriptive characteristics like age, education, occupation, number of pregnancies and type of birth ( $\mathrm{p}>0.05)$.

Of all the mothers participating in the study, $71 \%$ continued to breastfeed, $29 \%$ did not breastfeed, $13.5 \%$ could not produce breastmilk and $11.3 \%$ did not breastfeed since their babies rejected breastmilk. The longest duration of exclusive breastfeeding was two months (17.7\%). Thirty-four percent of the mothers fed their babies with breastmilk and formula instead of exclusive breastfeeding. The most frequent three responses to the question what benefits breastmilk has for babies are that it protects against diseases (59.6\%) and supports growth of babies (37.6\%) and strengthens immunity of babies (19.6\%). However, one mother said she did not know that breastmilk has any benefits and another mother said breastmilk did not have any benefits. When the mothers were asked what benefits breastfeeding has for mothers, $48.9 \%$ reported it accelerated weight loss, $14.22 \%$ reported it made mother-baby bonding stronger and $7.8 \%$ reported it protected against breast cancer. However, it was striking that $28.4 \%$ of the mothers said breastfeeding was not beneficial to mothers.

\section{DISCUSSION}

In the present study, we found that mothers receiving counselling about breastmilk and breastfeeding during antenatal care initiated breastfeeding at a higher rate in the first hour and breastfed their babies in the first six months 


\begin{tabular}{|c|c|c|c|c|c|c|c|c|}
\hline \multirow[t]{3}{*}{$\begin{array}{l}\text { Exclusive breastfeeding for the } \\
\text { first six months of life }\end{array}$} & \multicolumn{4}{|c|}{$\begin{array}{l}\text { Receiving counselling about } \\
\text { breastfeeding }\end{array}$} & \multicolumn{2}{|c|}{ Total } & \multirow[t]{3}{*}{ Test } & \multirow[t]{3}{*}{$\mathbf{p}$} \\
\hline & \multicolumn{2}{|c|}{ Yes } & \multicolumn{2}{|c|}{ No } & & & & \\
\hline & $\mathbf{n}$ & $\%$ & $\mathbf{n}$ & $\%$ & $\mathbf{n}$ & $\%$ & & \\
\hline Yes & 12 & 22.5 & 1 & 2.5 & 13 & 9.2 & & \\
\hline No & 89 & 77.5 & 39 & 97.5 & 128 & 90.7 & $\chi 2=35.122$ & $\mathrm{p}=\mathbf{0 . 0 0 4}$ \\
\hline Total & 101 & 100 & 40 & 100 & 141 & 100 & & \\
\hline \multicolumn{9}{|l|}{ Time of the first breastfeeding } \\
\hline Within the first one hour of birth & 35 & 34.7 & 5 & 12.5 & 40 & 28.4 & & \\
\hline 1 hours after birth & 66 & 65.3 & 35 & 87.5 & 101 & 71.6 & $\chi 2=6.920$ & $\mathrm{p}=0.009$ \\
\hline Total & 101 & 100 & 40 & 100 & 141 & 100 & & \\
\hline
\end{tabular}

exclusively with mother milk at higher rates compared to mothers not receiving counselling. This result underlines the importance of breastfeeding related counselling during antenatal care. Research shows that mothers offered to counselling about breastmilk and breastfeeding by nurses/midwives breastfeed their babies for a longer period of time..$^{21,22}$ In a study by Tokat and Okumuş (2013), antenatal training offered to strengthen perceived breastfeeding self-efficacy was found to achieve its goal and increase breastfeeding success. ${ }^{18}$ Moreover, the presence of the mothers not knowing benefits of breastfeeding for babies and thinking that breastfeeding is beneficial neither for mothers nor for babies reveals a need for specific counselling about breastfeeding.

In this study, we observed that $92.2 \%$ of the mothers got antenatal care in their latest pregnancy. Other studies carried out in different parts of Turkey also showed that about all women got antenatal training. ${ }^{20,23}$ Turkish Ministry of Health states in Antenatal Care Management Guide that pregnant women in Turkey should be followed minimum four times during their pregnancies. In the current study, the finding that $68 \%$ of the mothers got antenatal care five times or more shows that they were offered sufficient antenatal care in accordance with the guide created by the ministry. The rate of the women receiving adequate antenatal care in Turkey was reported to be $39.7 \%$ by Etiler et al., $51.6 \%$ by Çetin et al., and $48.1 \%$ by Omaç et al. ${ }^{17,23,24}$ In a study in Latin American countries, the rate of women receiving sufficient antenatal care was found to be $24.5 \% .{ }^{25}$ Based on data from TPHS 2013 , the rate of women getting antenatal care in their recent pregnancy was 92\% in 2008 and increased to $97 \%$ in 2013 in Turkey. This shows that the rate of women not given antenatal care decreased by about $64 \%$. Furthermore, the rate of receiving sufficient antenatal care was $89 \%{ }^{7}$ The rates of receiving antenatal care and sufficient antenatal care found in the present study are consistent with those reported by TPHS 2013.
In the current study, $28.4 \%$ of the mothers started to breastfeed their babies within the first hour of giving birth; however, most of the mothers $(71.6 \%)$ could not start breastfeeding within the first hour of delivery. TPHS 2013 revealed that the rate of breastfeeding in the first hour of birth was $50 \%$. The rate of mothers unable to breastfeed within the first hour of birth was $69.9 \%$ in a study by Eker and Yurdakul (2006), 51.9\% in a study by Bolat et al., (2011), 47.4\% in a study by Ünsür, Gündoğan, Ünsür and Okan (2014), 34\% in a study by Awi and Alikor (2006), $47.1 \%$ in a study by Vieira et. al., (2010) and $41.1 \%$ in a study by Wang, Lau, Chow and Chan (2014). ${ }^{26-31}$ The rate of breastfeeding in the first hour of birth in the present study was found to be lower than those reported by TPHS 2013 and other studies. In addition, the WHO reported that breastfeeding rates of $0-29 \%, 30-49 \%, 50-89 \%$ and $90-100 \%$ in the first one hour of birth were poor, moderate, good and very good respectively. ${ }^{25,30} \mathrm{In}$ light of this classification, the rate of breastfeeding in the first hour found in the current study can be considered as poor. It was found to be higher in the mothers having lower education levels, having a vaginal birth and receiving counselling about breastmilk and breastfeeding. Thirty-five point one percent of primary school graduates and $24 \%$ of the mothers graduating from high school or having higher education levels breastfed their babies in the first hour. It was a favorable finding that the rate of mothers with lower education levels breastfeeding in the first hour was higher. In addition, there have been studies showing that type of birth is effective in the initiation of breastfeeding and that women having normal birth start breastfeeding earlier. ${ }^{17}$ Consistent with the literature, the present study revealed that $77 \%$ of the mothers giving vaginal birth and $1.9 \%$ of the mothers having caesarian section began breastfeeding in the first hour of birth and that about half of the latter group could breastfeed their babies ten hours after birth or later. The rate of exclusive breastfeeding in the first six months varies from country to country. It was reported to be $11.3 \%$ in the United States, $10.1 \%$ in 
Sweden and 7\% in Norway. ${ }^{27,33,34}$ According to data from TPHS 2013, it was $42 \%$ in 2008 and $30 \%$ in 2013 in Turkey. ${ }^{7}$ In the present study, $9.2 \%$ of the mothers having babies aged 6-24 months fed their babies only with breastmilk for the first six months and $9.8 \%$ of the mothers having babies aged 0-6 months still gave their babies breastmilk only. The rate of exclusive breastfeeding was $27.7 \%$ in a study by Ünsür et al. (2014) and $52.8 \%$ in a study by Bolat et al. (2011). ${ }^{27,28}$ Although breastfeeding is quite common in Turkey, both data from TPHS 2013 and from the present study indicate that exclusive breastfeeding is not very common as opposed to what is recommended.

\section{LIMITATIONS OF THE STUDY}

Since the study was carried out only in two family health care centers in a city located in Middle Anatolia in Turkey, results cannot be generalized to all mothers. The results are restricted by the time of the study, the questionnaire developed for the purpose of this study and self-reports of the mothers included in the study.

\section{CONCLUSION AND RECOMMENDATIONS}

Almost all the mothers in this study were found to get sufficient antenatal care in their last pregnancy. Receiving antenatal care did not significantly differ in terms of descriptive characteristics including age, education, number of pregnancy and spontaneous abortion. Seventy-one point six percent of the mothers offered antenatal care were shown to be informed about breastmilk and breastfeeding. A higher rate of the women getting this information breastfed their babies in the first hour of delivery and fed their babies only with breastmilk for the first six months of life. Considering this significant effect of breastfeeding counselling on earlier initiation of breastfeeding and exclusive breastfeeding for the first six months of life, it is obvious that this counselling should be offered as part of antenatal care. It can be recommended that nursing school curricula and in-service training should provide nurses and midwives with recent knowledge about breastfeeding and that they should be encouraged to emphasize breastfeeding while giving antenatal care. In accordance with evidence from studies on earlier breastfeeding and maintenance of breastfeeding, breastfeeding specific protocols should be created in health care centers. As well as training, peer counselling, i.e. getting advice from other women, can contribute to effective breastfeeding. When the media is thought to be one of the most important sources for providing individuals with knowledge, it can be recommended that programs underlining the importance of breastmilk and breastfeeding could appear more frequently.

\section{ACKNOWLEDGEMENT}

The author is grateful to all mother who participated in the study.

\section{REFERENCES}

1. World Health Organization. WHO Programme to map best reproductive health practice. WHO Antenatal Care Randomized Trial: manual for the implementation of the new model. Geneva: World Health Organization 2002, 1-2. http://apps.who.int/iris/bitstream/10665/42513/1/ WHO_RHR_01.30.pdf. Date accessed: 06.12.16.

2. Çatak B, Aksan AD, Zincir M. Karabük toplum sağlığı merkezi bölgesinde doğum öncesi bakım hizmetlerinin nicelik ve niteliği. TAF Preventive Medicine Bulletin, 2012; 11(2): 153-162.

3. Raatikainen, $\mathrm{K}$, Heiskanen $\mathrm{N}$, Heinonen $\mathrm{S}$. Under-attending free antenatal care is associated with adverse pregnancy outcomes. BMC Public Health, 2007; 7(1): 1.

4. The Society of Obstetricians and Gynaecologists of Canada. Healthy beginnings: guidelines for care during pregnancy and childbirth. Canada: The Society of Obstetricians and Gynaecologists of Canada 1998, https://sogc.org/wpcontent/uploads/2013/12/gui71EPS9812.pdf.

Date accessed: 05.12.2017.

5. Republic of Turkey Ministry of Health. Antenatal Care Management Guide. Ankara, Turkey: Republic of Turkey Ministry of Health General Directorate of Mother and Child Health and Family Planning; 2009, 2.

6. Pirinçci E, Polat A, Köroğlu A, Kumru S. Bir üniversite hastanesinde doğum yapan kadınların doğum öncesi bakım alma durumu ve etkileyen faktörler. ADÜ Tıp Fakültesi Dergisi, 2010; 11(2): 1-7.

7. Hacettepe University Institute of Population Studies. 2013 Turkey Demographic and Health Survey. Hacettepe University Institute of Population Studies, T.R. Prime Ministry Undersecretary of State Planning Organization and TUBITAK, 2014, 119-120, Ankara.

8. Willumen J. Breastfeeding education for increased breastfeeding duration: Biological, behavioural, and contextual rationale. World Health Organization. eLibrary of Evidence for Nutrition Actions (eLENA), 2013, 1. http://www. who. int/elena/using/en. Date accessed: 25.02.2017.

9. Hanson LA, Korotkova M, Haversen L, MattsbyBaltzer I, Hahn-Zoric M, Silfverdal, SA et.al. Breast-feeding, a complex support system for the offspring. Pediatrics International 2002; 44(4): 347-352.

10. Arenz S, Rückerl R, Koletzko B, Von Kries R. Breast-feeding and childhood obesity-a 
systematic review. Int J Obes 2004; 28(10): 12471256.

11. Harder T, Bergmann R, Kallischnigg G, Plagemann A. Duration of breastfeeding and risk of overweight: a meta-analysis. Am J Epidemiology 2005; 162(5): 397-403.

12. Lumbiganon P, Martis R, Laopaiboon M, Festin MR., Ho JJ, Hakimi M. Antenatal breastfeeding education for increasing breastfeeding duration. The Cochrane Library 2012, 6.

13. Victora C, Barros A. Effect of breastfeeding on infant and child mortality due to infectious diseases in less developed countries. The Lancet 2000; 355(9202): 451- 455.

14. Balyakina E, Fulda KG, Franks SF, Cardarelli KM, Hinkle K. Association between healthcare provider type and intent to breastfeed among expectant mothers. Matern Child Health J 2016; 20(5): 993-1000.

15. Wight NE, Cordes R, Chantry CJ, Howard CR, Lawrence RA, Marinelli KA, et al. ABM clinical protocol\# 3: hospital guidelines for the use of supplementary feedings in the healthy term breastfed neonate, revised 2009. Breastfeeding Medicine 2009; 4(3): 175-183.

16. Şahin H, Yılmaz M, Aykut M, Balcı E, Sağıroğlu M, Öztürk A. Kayseri'de iki toplum sağlığ1 merkezine başvuran annelerde emzirme sorunları ve risk etmenleri. Türk Pediatri Arşivi 2013; 48(2): 145-151.

17. Çetin F, Güneş G, Karaoğlu L, Üstün Y. Turgut Özal Tip Merkezinde doğum yapan annelerin doğum öncesi bakım alma ve emzirmeye başlama durumları ve etkileyen faktörler. Turgut Özal Tip Merkezi Dergisi 2005; 12(4):247-252.

18. Tokat MA, Okumuş H. Emzirme öz-yeterlilik algısını güçlendirmeye temelli antenatal eğitimin emzirme öz-yeterlilik algısına ve emzirme başarısına etkisi Hemşirelikte Eğitim ve Araştırma Dergisi 2013;10(1): 21-29.

19. Dyson L, McCormick F, Renfrew MJ. Interventions for promoting the initiation of breastfeeding. Cochrane Database Syst Rev 2005; 2(2): 3 .

20. Küçük E, Çan G, Toptas M. Giresun 1 nolu saglık ocağı bünyesinde doğum yapan kadınların doğum öncesi, doğum ve doğum sonu bakım alma sıklığı. 9. Ulusal Halk Saglıgı Kongresi Bildiri Özet Kitabı 2004, 232, Ankara.

21. Eker A, Yurdakul M. Annelerin bebek beslenmesi ve emzirmeye ilişkin bilgi ve uygulamaları. Sürekli Tıp Eğitimi Dergisi 2006; 15(9): 158-163.

22. Turan M. Doğum sonrasi erken dönemde, doğru teknik ile emzirmenin tek başına anne sütü ile beslenme süresine etkisi. İstanbul Tıp Fakültesi Dergisi 2000; 63(3): 286-292.

23. Etiler N, Aktekin R, Çapar H. Antalya kent merkezindeki bir sağlık ocağı bölgesinde doğum öncesi bakım hizmetlerinin değerlendirilmesi. Sağl1k ve Toplum 2000;3:41-5.

24. Omaç M, Güneş G, Karaoğlu L, Pehlivan E. Arapgir devlet hastanesine başvuran gebelerin doğum öncesi bakım hizmetlerinden yararlanma durumları ve etkileyen faktörlerin değerlendirilmesi. Firat Tıp Dergisi 2009; 14(2): 115-119.

25. Paredes I, Hidalgo L, Chedraui P, Palma J, Eugenio J. Factors associated with inadequate prenatal care in Ecuadorian women. Int J Gynecol Obstet. 2005; 88(2): 168-172.

26. Bolat F, Uslu S, Bolat G, Bülbül A, Arslan S, Çelik $M$, ve ark. İlk altı ayda anne sütü ile beslenmeye etki eden faktörler. Çocuk Dergisi 2011; 11(1): 5-13.

27. Ünsür KE, Gündoğan DB, Ünsür TM, Okan FF. Emziren annelerin emzirme ile ilgili bilgi ve tutumlarının değerlendirilmesi. Euras J Fam Med.2014; 3(1):33-40.

28. Awi DD, Alikor EAD. Barriers to timely initiation of breastfeeding among mothers of healthy full-term babies who deliver at the University of Port Harcourt Teaching Hospital. Nigerian Journal Of Clinical Practice 2006; 9(1): 57-64.

29. Vieira TO, Vieira GO, Giugliani ERJ, Mendes CM, Martins CC, Silva LR. Determinants of breastfeeding initiation within the first hour of life in a Brazilian population: cross-sectional study. BMC Public Health 2010;10(1):1.

30. Wang W, Lau Y, Chow A, Chan KS. Breastfeeding intention, initiation and duration among Hong Kong Chinese women: a prospective longitudinal study. Midwifery 2014; 30(6):678687.

31. Baker EJ, Sanei LC, Franklin N. Early initiation of and exclusive breastfeeding in large-scale community-based programmes in Bolivia and Madagascar. Journal of Health, Population and Nutrition 2006; 530-539.

32. Al-Sahab B, Lanes A, Feldman M, Tamim H. Prevalence and predictors of 6-month exclusive breastfeeding among Canadian women: a national survey. BMC Pediatrics 2010; 10(1):1.

33. Liu J, Shi Z, Spatz D, Loh R, Sun G, Grisso J. Social and demographic determinants for breastfeeding in a rural, suburban and city area of South East China. Contemporary Nurse 2013; 45(2): 234-243.

34. Turan M. Doğum sonrasi erken dönemde, doğru teknik ile emzirmenin tek başına anne sütü ile beslenme süresine etkisi. İstanbul Tip Fakültesi Dergisi 2000; 63(3): 286-292. 